\title{
The child's welfare in a European perspective
}

\section{Rob George*}

\section{CONTENTS}

The Child's Welfare in European Perspective.......................................................... 1

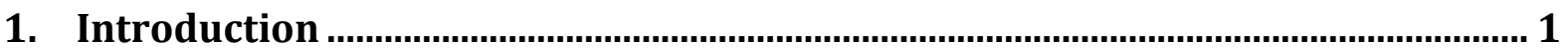

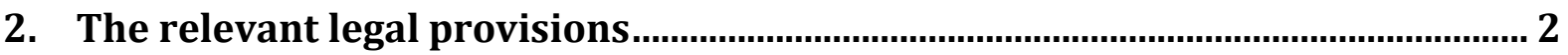

3. Welfare and human rights - the original analysis ............................................. 5

4. Recent decisions of the ECtHR ................................................................................ 9

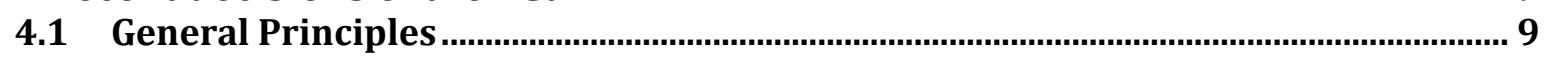

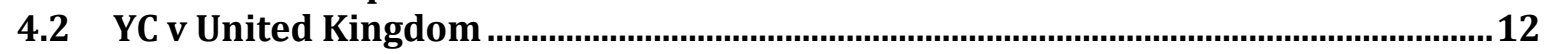

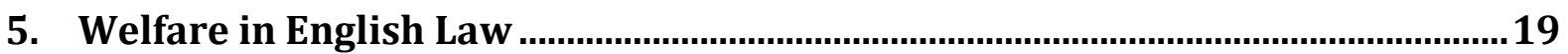

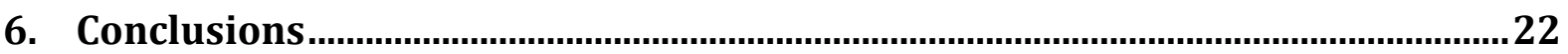

\section{INTRODUCTION}

Family law in domestic legal systems across Europe gives special prominence to the welfare or best interests of children in disputes concerning their upbringing. ${ }^{1}$ These domestic provisions receive support from the United Nations Convention on the Rights of the Child 1989, which provides that, in all actions concerning children, 'the best interests of the child shall be a primary consideration'. ${ }^{2}$ The same language has, more recently, been used in the Charter of Fundamental Rights of the European Union. ${ }^{3}$

While domestic provisions often use slightly different language from these international documents, the idea that the child's welfare amounts to a special consideration in decisions regarding their upbringing is widespread. However, despite the dominance of this welfare approach across Europe, there is a long-standing question about whether an approach to child law focused on the child's welfare is compatible with the requirements of the European Convention on Human Rights (ECHR) as interpreted by the European Court of Human Rights (ECtHR). The details will vary from jurisdiction to jurisdiction, but the

\footnotetext{
*I have endeavoured to make the law as stated in this chapter up-to-date as at 17 January 2014.

${ }^{1}$ See, e.g., Children Act 1989, s 1(1) (England and Wales); Code Civil, article 373-2 (France); Bürgerliches Gesetzbuch, article 1671 (Germany); Civil Code, article 92 (Spain).

${ }^{2}$ United Nations Convention on the Rights of the Child 1989, article 3.

${ }^{3}$ Charter of Fundamental Rights of the European Union 2010, article 24(2).
} 
widespread use of the welfare approach means that the core of the discussion is relevant across Europe. However, the question has been particularly well discussed by academics and judges in England, and so this chapter focuses on this debate as seen in the English context.

For some time, particularly in the aftermath of the implementation of the Human Rights Act 1998 in England (the Act gives the rights contained in the ECHR direct effect in English domestic law), there was a view amongst academic lawyers that the English welfare approach was inadequate from a human rights perspective. ${ }^{4}$ However, this chapter suggests that a re-assessment of the meaning of the welfare principle in domestic law, coupled with an analysis of recent cases from the ECtHR, may call for further thought to be given to this conclusion.

\section{THE RELEVANT LEGAL PROVISIONS}

The focus of this chapter will be on two particular provisions of English law, coming from the Children Act 1989 and the Adoption and Children Act 2002. The former deals with both disputes between parents about children's upbringing and disputes between the state and the family about child protection matters, which English family lawyers refer to as 'private law' and 'public law' matters respectively. The Adoption and Children Act, on the other hand, applies only to adoption matters, which tend to come up as part of serious child protection matters. In all these cases, the welfare of the individual child is said to be the 'paramount consideration' in decisions concerning the child's upbringing. ${ }^{5}$

Looking at these provisions in more detail, it is apparent that both Acts contain a statement about the child's welfare being the paramount consideration, although not in identical terms. The Children Act says:

When a court determines any question with respect to-

(a) the upbringing of a child ...

\footnotetext{
${ }^{4}$ While arguments to similar effect have been made in one or two cases (see, e.g., the arguments of Philip Cayford in Payne v Payne [2001] EWCA Civ 166, [2001] 1 FLR 1052), in general practising lawyers seem not to have favoured this line of attack.

${ }^{5}$ Different provisions about children's welfare apply in other contexts in English law, making welfare a consideration but not 'paramount' in the decision-making process. For example, when deciding whether to make a financial order after divorce, a court must 'have regard to all the circumstances of the case, first consideration being given to the welfare while a minor of any child of the family who has not attained the age of eighteen': Matrimonial Causes Act 1973, s 25(1). For another example, when a trustee seeks an order relating to the exercise of the trustee's duties under s 14 of the Trusts of Land and Appointment of Trustees Act 1996, one of several matters 'to which the court is to have regard' under s $15(1)$ is 'the welfare of any minor who occupies or might reasonably be expected to occupy any land subject to the trust as his home'.
} 
the child's welfare shall be the court's paramount consideration. ${ }^{6}$

The Adoption and Children Act, by contrast, says:

The paramount consideration of the court or adoption agency must be the child's welfare, throughout his life. ${ }^{7}$

Whether this difference is substantive or not is unclear. It has been held that a consideration of a child's welfare under the Children Act should focus not only on short-term questions, but should involve 'a medium-term and long-term view of the child's development' ${ }^{8}$ Indeed, it has been said that this assessment might, depending on the nature of the case, involve 'a judge dealing with a young child ... looking to the 22 nd century'. ${ }^{9}$ In such a case, it is hard to see that the Adoption and Children Act's instruction to consider welfare throughout the child's life would add much. The effect may be simply to make clear that adoption cases always involve life-long considerations; other decisions about children's upbringing may involve such questions, but equally may not depending on the nature of the case. ${ }^{10}$

In both Acts, these general statements of welfare paramountcy are then supplemented by lists of relevant considerations which decision-makers should take into account when assessing welfare. ${ }^{11}$ The Children Act's list, in s 1(3), is known as the welfare checklist:

(a) the ascertainable wishes and feelings of the child concerned (considered in the light of his age and understanding);

(b) his physical, emotional and educational needs;

(c) the likely effect on him of any change in his circumstances;

(d) his age, sex, background and any characteristics of his which the court considers relevant;

(e) any harm which he has suffered or is at risk of suffering;

(f) how capable each of his parents, and any other person in relation to whom the court considers the question to be relevant, is of meeting his needs;

(g) the range of powers available to the court under this Act in the proceedings in question.

\footnotetext{
${ }^{6}$ Children Act 1989, s 1(1).

${ }^{7}$ Adoption and Children Act 2002, s 1(2).

${ }^{8}$ Re O (Contact: Imposition of Conditions) [1995] 2 FLR 124 (CA) at 129.

${ }^{9} \operatorname{Re} G$ (Education: Religious Upbringing) [2012] EWCA Civ 1233, [2012] 3 FCR 524 at [26].

${ }^{10}$ In $\operatorname{Re} G$, ibid, Munby LJ notes as an example that '[i]f the dispute is about whether the child should go on a school trip the judge will be concerned primarily with the present rather than the future'.

${ }^{11}$ Similar lists of factors are found in other European jurisdictions: see, e.g., the French Code Civil, article 373-2-11.
} 
The list in s 1(4) of the Adoption and Children Act 2002 is in many ways similar to its Children Act counterpart:

The court or adoption agency must have regard to the following matters (among others) -

(a) the child's ascertainable wishes and feelings regarding the decision (considered in the light of the child's age and understanding),

(b) the child's particular needs,

(c) the likely effect on the child (throughout his life) of having ceased to be a member of the original family and become an adopted person,

(d) the child's age, sex, background and any of the child's characteristics which the court or agency considers relevant,

(e) any harm (within the meaning of the Children Act 1989) which the child has suffered or is at risk of suffering,

(f) the relationship which the child has with relatives, and with any other person the court or agency considers the relationship to be relevant including-

(i) the likelihood of any such relationship continuing and the value to the child of its doing so,

(ii) the ability and willingness of any of the child's relatives, or of any such person, to provide the child with a secure environment in which the child can develop, and otherwise to meet the child's needs,

(iii) the wishes and feelings of the child's relatives, or of any such person, regarding the child.

At the European level, the key provision is in the European Convention on Human Rights and Fundamental Freedoms 1950 (ECHR), incorporated into English domestic law by the Human Rights Act 1998. Article 8 of the ECHR provides as follows:

1. Everyone has the right to respect for his private and family life, his home and his correspondence.

2. There shall be no interference by a public authority with the exercise of this right except such as is accordance with the law and is necessary in a democratic society in the interests of national security, public safety or the economic well-being of the country, for the prevention of disorder or crime, for the protection of health or morals, or for the protection of the rights and freedoms of others. 


\section{WELFARE AND HUMAN RIGHTS - THE ORIGINAL ANALYSIS}

Much of this chapter focuses on asking whether recent developments in the jurisprudence of the ECtHR call for a reconsideration of some of the previous thinking about the interrelationship between welfare and human rights which was seen in the English academic literature. In order to conduct such an analysis, it is necessary to have an idea of what that previous thinking was. A useful summary of the position is given by Claire Simmonds (Fenton-Glynn):

commentators have argued [that] the approach to decision-making, the method of reasoning and potentially the result are fundamentally different under these laws. The English law requires the judge to start from the premise that the child's welfare will be the 'sole consideration' and thus will determine the outcome ( $J v C$ [1970] AC 688), and consider the rights of other parties only as far as they contribute to promoting the child's best interests. On the other hand, article 8 requires the judge first to evaluate the rights of the applicant (be that parent or child) to respect for family and private life, and then determine whether the infringement of this right has been in accordance with the law, pursued a legitimate aim, and was necessary in a democratic society. ${ }^{12}$

The English courts have long taken the view that there is no conflict between domestic law making the child's welfare 'paramount' (or between the long-held interpretation of such provisions) and the requirements of the ECHR. For example, in Re KD (Access: Principles), ${ }^{13}$ it was said that there was 'no inconsistency of principle' between a welfare analysis and a rights analysis; ${ }^{14}$ and such difference as was perceived was 'semantic only and lies only in differing ways of giving expression to [a] single common concept'. ${ }^{15}$ That was in the context of a child being placed for adoption following wardship proceedings. More recently, in an adoption case decided under the Adoption Act 1975, the House of Lords reiterated this view:

Under Art 8 the adoption order must meet a pressing social need and be a proportionate response to that need ... Inherent in both these Convention concepts is a balancing exercise, weighing the advantages and the disadvantages. But this balancing exercise, required by Art 8 , does not differ in substance from the like-balancing exercise undertaken by a court when deciding whether, in the conventional phraseology of English law, adoption would be in the best interests of the child. The like considerations fall to be taken into account. Although the

\footnotetext{
${ }^{12}$ C Simmonds, 'Paramountcy and the ECHR: A Conflict Resolved?' [2012] Cambridge LawJournal 498, 498-99.

${ }^{13}$ Re KD (Access: Principles) [1988] 2 FLR 139 (HL).

${ }^{14}$ Ibid at 141 (Lord Templeman).

${ }^{15}$ Ibid at 153 (Lord Oliver).
} 
phraseology is different, the criteria to be applied in deciding whether an adoption order is justified under Art 8(2) lead to the same result as the conventional tests applied by English law. Thus, unless the court misdirected itself in some material respect when balancing the competing factors, its conclusion that an adoption order is in the best interests of the child, even though this would exclude the mother from the child's life, identifies the pressing social need for adoption (the need to safeguard and promote the child's welfare) and represents the court's considered view on proportionality. That is the effect of the judge's decision in the present case. Article 8(2) does not call for more. ${ }^{16}$

In this passage, the House reflected the view taken just nine months earlier in the Court of Appeal in a relocation case,${ }^{17}$ although the latter attracted more academic attention and criticism despite - or perhaps because of - its rather fuller engagement with the questions raised by the ECHR. ${ }^{18}$

In short, it is this view that was challenged by academics and, in understanding those criticisms, the work of four scholars might be thought particularly instructive. The most recent, and fullest, analysis comes from Shazia Choudhry and Jonathan Herring's 2010 book, European Human Rights and Family Law. ${ }^{19}$ Two earlier works can also usefully be drawn on, in the form of articles by Sonia Harris-Short, ${ }^{20}$ and by Choudhry and Helen Fenwick. ${ }^{21}$ Between them, these works offer a complete and widely respected analysis of the state of the authorities and the legal arguments from first principles as they were at the times they were written. ${ }^{22}$ It can therefore be accepted that they make the argument about the apparent

\footnotetext{
${ }^{16}$ Re B (Adoption: Natural Parent) [2001] UKHL 70, [2002] 1 FLR 196 at [31] (Lord Nicholls).
}

${ }^{17}$ Payne v Payne [2001] EWCA Civ 166, [2001] 1 FLR 1052.

${ }^{18}$ See, e.g., S Harris-Short, 'Family Law and the Human Rights Act 1998: Judicial Restraint or Revolution?' [2005] Child and Family Law Quarterly 329; S Choudhry and H Fenwick, 'Taking the Rights of Parents and Children Seriously: Confronting the Welfare Principle Under the Human Rights Act' [2005] Oxford Journal of Legal Studies 453; J Herring and R Taylor, 'Relocating Relocation' [2006] Child and Family Law Quarterly 517.

${ }^{19}$ S Choudhry and J Herring, European Human Rights and Family Law (Hart Publishing 2010); see also J Herring, 'The Human Rights Act and the Welfare Principle in Family Law: Conflicting or Complementary?' [1999] Child and Family Law Quarterly 223; J Herring, 'Farewell Welfare?' [2005] Journal of Social Welfare and Family Law 159.

${ }^{20}$ Harris-Short (n 18); S Harris-Short, 'The Adoption and Children Act 2002, the Welfare Principle and the Human Rights Act 1998 - A Missed Opportunity’ [2003] Child and Family Law Quarterly 119.

${ }^{21}$ Choudhry and Fenwick (n 18).

${ }^{22}$ See also J Eekelaar, Family Law and Personal Life (Oxford University Press 2007) 150: 'It seems certain that the interpretation given by the House of Lords to the duty to give paramount consideration to the best interests of the child when making a decision about the child's upbringing in $J v C$ cannot be followed, because it allowed weight to be given to the parents' interests only to the extent that they had a bearing on those of the child. But now the standards of Article 8 will have to be applied to the interests of all parties.' 
conflict between welfare and human rights as well as it can be made, although only a brief summary of the argument is given here, and inevitably some of the nuance is thereby lost.

To a greater or lesser extent, these works draw on broader criticisms that are made in the common law literature of the welfare principle and the decision-making process undertaken in pursuit of welfare solutions. ${ }^{23}$ These criticisms highlight a number of claimed deficiencies in the welfare approach, including its lack of predictability, the opaque nature of the reasoning process, and the alleged ${ }^{24}$ exclusion of an independent analysis of the interests of others concerned in the case because of the paramount consideration given to the child's best interests. ${ }^{25}$ In other words, these criticisms are accepted as part of the background against which the welfare and human rights debate is conducted.

Because these criticisms of the welfare principle are accepted, the apparent differences in the analytical process called for under a human rights approach are easy to see. The human rights approach is said to call for a 'parallel analysis' of all the independentlyheld interests of all those affected by a decision. Each person's rights, or interests, are to be identified, assessed and weighed independently, and then the decision-maker is required to conduct an over-arching balance of all the relevant interests when making a decision. ${ }^{26}$ Once these rights have been so analysed, the decision-maker is required to ask whether the interference is in accordance with law, is in pursuit of a legitimate aim, and is necessary in a democratic society.

It has long been clear that the interests of a child may be given some amount of priority in this process. As the ECtHR explained in Johansen v Norway in 1996, '[i]n carrying out this balancing exercise, the court will attach particular importance to the best interests of the child, which, depending on their nature and seriousness, may override those of the parent'. ${ }^{27}$ However, the key point in this statement of principle for commentators was the

\footnotetext{
${ }^{23}$ The classic work was R Mnookin, 'Child-Custody Adjudication: Judicial Functions in the Face of Indeterminacy' (1975) 39 Law and Contemporary Problems 226, with more recent analysis by J Eekelaar, 'The Interests of the Child and the Child's Wishes: The Role of Dynamic Self-Determinism' [1994] International Journal of Law and the Family 42 and H Reece, 'The Paramountcy Principle: Consensus or Construct?' (1996) 49 Current Legal Problems 267, amongst others.

${ }^{24}$ For the reasons why I say 'alleged' in relation to this final criticism, see below, text from $\mathrm{n} 76$.

${ }^{25}$ So, for example, Choudhry and Fenwick say that under a welfare analysis, 'the welfare of the child is ... the single deciding factor, that is, paramount over, and in fact displacing, all other considerations': Choudhry and Fenwick (n 18) 455.

${ }^{26}$ See generally $\operatorname{Re} S$ (A Child) (Identification: Restrictions on Publicity) [2004] UKHL 47, [2005] 1 FLR 591.

${ }^{27}$ Johansen v Norway (App No 17383/90) (1996) 23 EHRR 33 (ECtHR) at [78].
} 
phrase 'depending on their nature and seriousness' ${ }^{28}$ This point was said to demand a caseby-case assessment of the child's interests as compared with the interests of each other person involved in the case (primarily one or both parents, in most cases), rather than an assumption that the child's interests should always override anyone else's interests (which is what the welfare approach is said to involve) ${ }^{29}$

Consequently, while it was accepted that the child's interests could be given some degree of priority within a human rights analysis, it was not thought legitimate within that framework for the child's interests to be given 'paramountcy' in the sense in which that word is used in the English domestic context. ECtHR cases decided in the early part of the last decade that might have started to call some of these conclusions into question by taking a broader approach, such as Yousef $v$ The Netherlands in $2002,{ }^{30}$ were explained as outliers and exceptions, rather than as the start of a change. ${ }^{31}$ The question that this chapter explores is whether that conclusion should be revisited.

\section{RECENT DECISIONS OF THE ECtHR}

One reason why there may be reason to come back to the question of compliance between the English courts' approach to welfare and human rights stems from judgments from the ECtHR itself. Various decisions from the Grand Chamber and individual Chambers have re-stated a number of important principles and explored both the procedural and substantive contents of article 8 rights in relation to child law cases. From the English perspective, one case of particular interest is $Y C v$ United Kingdom, ${ }^{32}$ decided in March 2012. However, before turning to that case, a broader discussion of the emerging principles is in order.

${ }^{28}$ The omission of these words in Payne v Payne [2001] EWCA Civ 166, [2001] 1 FLR 1052 at [39] and by implication at [82] when referring to Johansen was a cause of particular criticism from commentators, since the selective quotation seemed so disingenuous: see S Harris-Short (n 18) 355; Herring and Taylor (n 18) 528. However, while the judges involved (Thorpe LJ and Butler-Sloss P) are, in the end, responsible for their judgments and for this serious omission, it is possible that the quotations adopted were taken, without further enquiry, from the submissions of counsel.

${ }^{29}$ See, e.g., Harris-Short (n 18) 355; Herring and Taylor (n 18) 528.

${ }^{30}$ Yousef $v$ Netherlands (App No 33711/95) [2003] 1 FLR 210 (ECtHR).

${ }^{31}$ See, for example, Harris-Short (n 19); R Tolson, 'The Welfare Test and Human Rights: Where's the Beef in the Sacred Cow?' (2005) (available 31 July 2015 at http://www.familylawweek.co.uk/site.aspx?i=ed307).

${ }^{32}$ YC v United Kingdom (App No 4547/10) [2012] 2 FLR 332 (ECtHR) (hereafter, YC v United Kingdom). 


\subsection{General Principles}

First, it is clear that article 8 contains both procedural and substantive aspects. Although the procedural elements are not the focus of this chapter, it may be noted that the overall question asked by the ECtHR is "whether the decision-making process was fair and afforded due respect to the applicant's rights under Art 8, ${ }^{33}$ This requires the court to ask whether 'the decision-making process leading to the [decision] by the domestic court was fair and allowed those concerned to present their case fully,. ${ }^{34}$ Court proceedings will often form only part of this assessment, ${ }^{35}$ but in regard to court judgments they have to be read in the context of the case as a whole to assess whether the reasons given are relevant and sufficient for the decision being taken. ${ }^{36}$ More broadly, it is necessary to ask:

whether the domestic courts conducted an in-depth examination of the entire family situation and of a whole series of factors, in particular of a factual, emotional, psychological, material and medical nature, and made a balanced and reasonable assessment of the respective interests of each person, with a constant concern for determining what the best solution would be for the ... child ... ${ }^{37}$

As this quotation demonstrates, there is a strong link between the procedural requirements of article 8 and the substantive elements. In order to satisfy the procedural element, an 'in-depth examination of the entire family situation and of a whole series of factors' is demanded; and in order to know what those factors are, it will be necessary to have regard to the substantive requirements of article 8 .

In terms of those substantive elements, it is fair to say that the European Court does not always speak with one voice. Indeed, insofar as this chapter suggests that recent cases may show a change in approach by the ECtHR, it is important to note that the Court has used many formulations over the years, and none appears to have become established for long. So for example, the ECtHR has described children's interests as being 'in every case of crucial

\footnotetext{
${ }^{33}$ YC v United Kingdom at [133].

${ }^{34}$ Neulinger and Shuruk $v$ Switzerland (App No 41615/07) [2011] 1 FLR 122 (hereafter, Neulinger $v$ Switzerland) at [139]; see also YC v United Kingdom at [138].

${ }^{35}$ The assessment looks at the total interaction between the family and whatever parts of the state are involved in the decision-making. In YCv United Kingdom at [146], it is clear that the fact that the local authority had done work to try to 'rebuild the family through the provision of support for alcohol abuse and opportunities for parenting assistance' was one key consideration in finding no breach of article 8.

${ }^{36}$ See, e.g., K and T v Finland (App No 25702/94) [2001] 2 FLR 707 at [154]; R and Hv United Kingdom (App No 35348/06) [2011] 2 FLR 1236 at [81].

${ }^{37}$ Neulinger $v$ Switzerland at [139].
} 
importance', ${ }^{38}$ and of 'particular importance', in addition to the Johansen v Norway 'nature and seriousness' approach. ${ }^{39}$ Indeed, the Johansen formulation continues to be seen from time to time: a recent example is Ahrens v Germany, where the Court said: 'Consideration of what lies in the best interests of the child concerned is of paramount importance in every case of this kind; depending on their nature and seriousness, the child's best interests may override that of the parents'. ${ }^{40}$

Other cases, however, appear to adopt a broader approach and, in particular, do not use the phrase from earlier cases about the 'nature and seriousness' of the child's interests. For example, in the child abduction case of Neulinger and Shuruk $v$ Switzerland, the Grand Chamber noted that 'there is currently a broad consensus - including in international law - in support of the idea that in all decisions concerning children, their best interests must be paramount'. ${ }^{41}$ The Grand Chamber then proceeded to explain, in substantive terms, what the child's best interests might mean:

The child's interest comprises two limbs. On the one hand, it dictates that the child's ties with its family must be maintained, except in cases where the family has proved particularly unfit. It follows that family ties may only be severed in very exceptional circumstances and that everything must be done to preserve personal relations and, if and when appropriate, to 'rebuild' the family ... On the other hand, it is clearly also in the child's interest to ensure its development in a sound environment, and a parent cannot be entitled under Art 8 to have such measures taken as would harm the child's health and development ... ${ }^{42}$

These points - both as to the general paramountcy of the child's welfare interests and as to the two limbs which need to be considered within that - have been paraphrased numerous times by individual Chambers hearing child law cases of various kinds. ${ }^{43}$ Indeed, in $R$ and $H$ $v$ United Kingdom, the Court said in terms that the principles from Neulinger have application beyond their immediate context: 'Although Neulinger ... concerned the relationship between Art 8 and the Hague Convention on Civil Aspects of International Child

\footnotetext{
${ }^{38} K$ and $T$ v Finland (App No 25702/94) [2001] 2 FLR 707 (Grand Chamber) at [154]; and similarly Scott $v$ United Kingdom (App No 24745/97) [2000] 2 FCR 560 (ECtHR) at 572.

${ }^{39}$ Yousef $v$ Netherlands (App No 33711/95) [2003] 1 FLR 210 (EctHR) at [91].

${ }^{40}$ Ahrens v Germany (App No 45071/09) [2012] 2 FLR 483 (ECtHR) at [63]. See also C v Finland (App No 18249/02) [2006] 2 FLR 597 at [54].

${ }^{41}$ Neulinger $v$ Switzerland at [135].

${ }^{42}$ Ibid at [136]. This point can be seen to build on the earlier decision in $K$ and $T v$ Finland (App No 25702/94) [2001] 2 FLR 707 (Grand Chamber) at [155].

${ }^{43}$ See, e.g., Šneersone and Kampanella v Italy (App No 14737/09) [2011] 2 FLR 1322 at [85(v)]; YC v United Kingdom at [134].
} 
Abduction 1980, the court considers the principles set out above are equally applicable to domestic care and adoption proceedings'. ${ }^{44}$

\subsection{YC v United Kingdom}

As an application of these general principles, and in terms of advancing the discussion about the relationship between the English domestic law's concept of the welfare principle and the principles articulated by the European courts in relation to article 8, the case of $Y C v$ United Kingdom has particular interest. The case involved a child (aged 8 at the time of the domestic proceedings) whose parents were in a volatile, violent and alcohol-fuelled relationship, which was of sufficient seriousness for the local authority to be seeking a care order with a view to placing the child for adoption. Various support measures had been tried before court proceedings began, and on the verge of the trial the mother proposed that she should be assessed independently of the father, since she said that she was willing to separate from him if that would allow her to keep the child in her care. The local authority thought the mother to be incapable of effectively separating from the father within a realistic timescale given the child's needs because of the nature of her relationship with the father, but the Family Proceedings Court ordered further investigation and assessment. ${ }^{45}$ The local authority and child's guardian appealed to the County Court, and the judge allowed the appeal and made a final care order ${ }^{46}$ together with an order placing the child for adoption without the parents' consent. ${ }^{47}$ The mother's application for permission to appeal to the Court of Appeal was refused. $^{48}$

As a test of the English approach to decisions about children's welfare, the process and reasoning in $Y C v$ United Kingdom provides a good example. The decision in the County Court - which, being the final substantive decision in the case, was the main focus of the ECtHR analysis - was brief and contained little by way of detailed analysis, ${ }^{49}$ and therefore provides a good test case of the kind of process and reasoning which will survive review by

\footnotetext{
${ }^{44} R$ and $H v$ United Kingdom (App No 35348/06) [2011] 2 FLR 1236 at [74].

${ }^{45}$ Children Act 1989, s 38(6).

${ }^{46}$ Children Act 1989, s 31.

${ }^{47}$ Adoption and Children Act 2002, ss 22 and 52.

${ }^{48}$ Part of the Court of Appeal's reasoning is reproduced in YC v United Kingdom at [86]-[88].

${ }^{49}$ In the ECtHR, Judge de Gaetano's dissenting judgment described the County Court decision as 'most unorthodox' and as 'strange, to put it mildly': YCv United Kingdom at [2] and [4] of the minority judgment.
} 
the ECtHR.

For the majority in the ECtHR, the starting point was to ask what the judge ought to have done in order to comply with the requirements of article 8. Unsurprisingly, this analysis started by noting the standard three-stage approach to an assessment of whether the interference with the applicant's article 8 rights was justified, 'namely whether it was in accordance with the law, pursued a legitimate aim and was necessary in a democratic society. 50

While setting out the general principles seen in the previous section, the Court noted that in assessing a child's best interests, and in assessing the proportionality of measures proposed in the pursuit of those interests, many factors will have to be weighed; the Court had not previously thought it right to attempt to list those factors, since they will vary too much from case to case. ${ }^{51}$ Nonetheless, in a very significant passage the Court went on:

However, [the court] observes that the considerations listed in s 1 of the 2002 [Adoption and Children] Act ... broadly reflect the various elements inherent in assessing the necessity under Art 8 of a measure placing a child for adoption. In particular, it considers that in seeking to identify the best interests of a child and in assessing the necessity of any proposed measure in the context of placement proceedings, the domestic court must demonstrate that it has had regard to, inter alia, the age, maturity and ascertained wishes of the child, the likely effect on the child of ceasing to be a member of his original family and the relationship the child has with relatives. ${ }^{52}$

Leaving aside for a moment the question of whether the 'checklists' of factors in either s 1(3) of the Children Act or s 1(4) of the Adoption and Children Act do in fact 'broadly reflect' an article 8 analysis, ${ }^{53}$ it is worth noting that the majority judges supported their view on this point by reference to the English Court of Appeal decision in EHv A London Borough Council, ${ }^{54}$ which also involved care and placement orders. The relevant part of that case is worth some attention. Giving the first judgment, Baron J said this:

The judge was making a very draconian order. As such, he was required to balance each factor within the checklist in order to justify his conclusions and determine whether the final outcome

${ }^{50}$ YC v United Kingdom at [130]; see generally Choudhry and Herring (n 19), ch 1.

${ }^{51}$ YC v United Kingdom at [135]. It might be noted that the same view was taken by the Law Commission in its report that led to the Children Act 1989 - while general considerations could be listed in the welfare checklist, specific factors would have to be formulated on a case-by-case basis: Law Commission, 'Review of Child Law: Guardianship and Custody', Law Com No 172 (HMSO 1988).

${ }^{52}$ YC v United Kingdom at [135].

${ }^{53}$ See below, text from n 68.

${ }^{54}$ EH v A London Borough Council [2010] EWCA Civ 344, [2010] 2 FLR 661. 
was appropriate. Accordingly, because this analysis is entirely absent, his failure to mention the provisions of the 1989 Act and deal with each part of s 1(3) undermines his conclusions and his orders ...

In a case where the care plan leads to adoption the full expression of the terms of Art 8 must be explicit in judgment because, ultimately, there can be no greater interference with family life. Accordingly, any judge must show how his decision is both necessary and proportionate. In this case what the judge said was 'removing the children from their mother without good reason ... would be a tragedy for them, quite apart from the mother'. With all due respect to him, this does not demonstrate that he had Art 8 well in mind. ${ }^{55}$

In other words, the relevant domestic authority on which the ECtHR made its assessment stated explicitly that a judge must go through and consider each factor on the checklist in turn. ${ }^{56}$ This point appeared to be important for the majority's approach to $Y C$ because it meant that each factor within the welfare checklist - which 'broadly reflect the various elements inherent in assessing the necessity under Art 8 of a measure placing a child for adoption ${ }^{, 57}$ - would be expressly considered and weighed in the final analysis by the judge. However, it is at least questionable whether the $E H$ case is representative of the general approach of the English courts when it comes to welfare checklists.

Certainly, the House of Lords has said that 'in any difficult or finely balanced case ... it is a great help to address each of the factors in the list $;{ }^{58}$ but in the same paragraph, Lady Hale said that 'any experienced family judge is well aware of the contents of the statutory checklist and can be assumed to have had regard to it whether or not this is spelled out in a judgment'. ${ }^{59}$ Much the same thought process is apparent from numerous Court of Appeal cases including, ${ }^{60}$ just three months after EH $v$ A London Borough, the evidently uncomfortable comments of a differently constituted Court of Appeal. In $M v$ Neath Port

\footnotetext{
${ }^{55}$ Ibid at [61] and [64] (emphasis added).

${ }^{56}$ Wall LJ, agreeing with Baron J, similarly observed that 'these are not hoops imposed by Parliament and the appellate judiciary designed to make the life of the hard-pressed circuit judge even more difficult than it is already. They are not boxes to be ticked so that this court can be satisfied that the judge has gone through the motions': EH v A London Borough Council [2010] EWCA Civ 344, [2010] 2 FLR 661 at [96].

${ }^{57}$ YC v United Kingdom at [135].

${ }^{58}$ Re G (Residence: Same-Sex Parents) [2006] UKHL 43, [2006] 2 FLR 629 at [40].

${ }^{59}$ Ibid.

${ }^{60}$ See e.g. $H$ v H (Residence Order: Leave to Remove from Jurisdiction) [1995] 1 FLR 529 (CA) at 532: 'one should remember, that when one calls it a checklist, that it is not like the list of checks which an airline pilot has to make with his co-pilot, aloud one to the other before he takes off. The statute does not say that the judge has to read out the seven items in s 1(3) and pronounce his conclusion on each. Sometimes judges will do that, maybe more often than not; but it is not mandatory.'
} 
Talbot $C B C$, Wilson LJ (giving the judgment of the Court) described Baron J's view as 'arresting'. Despite acknowledging the importance of not issuing conflicting views from the Court of Appeal where possible, his Lordship said this:

it is, of course, unusual for a judge to be required to include any particular set of words in his judgment. The more usual approach is to assume, unless he has demonstrated to the contrary, that the judge knew how to perform his functions and what matters to take into account ... Perhaps when the next appeal against a placement order arrives before us upon the basis of a complaint that there was no express reference to Art 8, we will have to consider whether, when considered in context, the instruction of this court in $E H$ 's case is as absolutist as it at first appears. $^{61}$

Two points arise from this discussion. First, it is far from clear that the domestic cases taken as a whole give much support to the ECtHR's view that English judges must demonstrate explicitly how they have considered, weighed and balanced all the factors on the checklist. ${ }^{62}$ The general view is rather that, as with any area of law where the judge is considering, weighing and balancing a well-known list of factors, his judgment should be 'read on the assumption that, unless he has demonstrated the contrary, the judge knew how he should perform his functions and which matters he should take into account'. ${ }^{63}$

Even leaving that point aside, though, some may wonder why the majority judgment in the ECtHR gave such focus to the EH v A London Borough approach, since it is clear that the County Court judge in $Y C$ had not, in fact, given the factors on the checklist any particular regard at all. As the majority judgment explains:

The court acknowledges that ... the county court judge did not make express reference to the relevant considerations arising under Art 8 of the European Convention ... or to the various factors set out in s 1 of the 1989 Act and s 1 of the 2002 Act ... However, as outlined above, it is clear that he directed his mind, as required under Art 8 of the European Convention, to [the child's] best interests and that, in reviewing the applicant's application for a further assessment, considered whether in the circumstances rehabilitation of [the child] to his biological family

${ }^{61} M v$ Neath Port Talbot CBC [2010] EWCA Civ 821, [2010] 2 FLR 1827 at [22], citing Piglowska v Piglowski [1999] 2 FLR 763 (HL) at 784.

62 This view is also likely to dominate in future, since Lord Wilson has subsequently become a Justice of the Supreme Court, while Lady Hale (the other family law specialist on the Supreme Court) was already on record as taking a similar view about the checklist (see Re G (Residence: Same-Sex Parents) [2006] UKHL 43, [2006] 2 FLR 629 at [40]).

${ }^{63}$ Piglowska v Piglowski [1999] 2 FLR 763 (HL) at 784. This point has been repeated frequently in recent Court of Appeal judgments, showing its ongoing application: see, e.g., Re B (A Child) [2012] EWCA Civ 1475 at [5]; Re M (Children) [2012] EWCA Civ 1710 at [47]; Re TG (Care Proceedings: Case Management: Expert Evidence) [2013] EWCA Civ 5, [2013] 1 FLR 1250 at [38]; Re H (A Child) [2013] EWCA Civ 72 at [69]. 
was possible. He concluded that it was not. In reaching that decision he had regard to various relevant factors and made detailed reference to the reports and oral evidence of the social worker, the guardian (whose report was based on full consideration of the welfare checklist) and [a psychologist], all of whom identified the various issues at stake ... ${ }^{64}$

It is difficult to understand why the Court chose to emphasise the importance of assessing and weighing the individual factors identified by the checklist given that, when it came to analyse the decision under review, such an explicit process was clearly not judged to be necessary in order to make the process compliant with article 8. In his scathing dissent, Judge de Gaetano observed that this section of the majority judgment (like the Court of Appeal's 'cavalier' approach $^{65}$ when refusing the mother permission to appeal) 'assumes that the judge had at some stage applied his mind properly in considering all the matters mentioned in s 1(4) of the 2002 Act', ${ }^{66}$ despite the fact that the judge had not demonstrated such application in his judgment. For Judge de Gaetano, that 'gratuitous assumption' was inadequate to save the County Court judgment from violating article 8:

There is no reference, specific or otherwise, to the checklist in s 1(4) of the 2002 Act. There is no reference to the rights enjoyed by both parents and children under the European Convention, to Art 8 or to any principle of proportionality. Whatever the guardian may have analysed and recommended in her report ... it was for the judge to apply independently his mind to the relevant and sufficient considerations and to show unequivocally in the judgment that he had done so. ${ }^{67}$

However, despite his criticism of the majority's assessment of the County Court judgment, there is little indication that Judge de Gaetano disagreed with the majority's construction of the question or, put another way, the view that the points in the welfare checklist would 'broadly reflect' the issues to be considered and weighed in an article 8 assessment. ${ }^{68}$ This may be the most crucial part of $Y C$ in terms of the debate about the compatibility of the welfare principle as understood in English domestic law and the ECHR; and, as Simmonds says, 'this easy acceptance of the compatibility of English law with an article 8 analysis [by the Court in $Y C$ ] may disappoint some authors'. ${ }^{69}$ Indeed, defending the welfare principle against human rights arguments has been deeply unfashionable in academic circles but, as

\footnotetext{
${ }^{64}$ YC v United Kingdom at [147].

${ }^{65}$ YC v United Kingdom at [1] of the minority judgment.

${ }^{66} Y C v$ United Kingdom at [5] of the minority judgment

${ }^{67}$ YC v United Kingdom at [4] of the minority judgment.

${ }^{68}$ YC $v$ United Kingdom at [135].

${ }^{69}$ Simmonds (n 12) 500 .
} 
Simmonds says, $Y C$ and other recent cases suggest that 'paramountcy, in the English sense, may not be so alien to the ECtHR as it once was'. ${ }^{70}$

Simmonds cautions that one should be careful not to read too much into $Y C$ in two different regards. The first, with which no dispute could be taken, is regarding the crucial role of the procedural protections given under article 8 , especially the meaningful participation in court and pre-court processes of all those involved. The second relates to the scope of the $Y C$ approach.

From a theoretical perspective, the question to be considered here is whether the ECtHR is right to say that the welfare checklist in the Adoption and Children Act (and, by implication therefore, the welfare approach more generally) does indeed 'broadly reflect' an article 8 analysis. The ECtHR's discussion of this point was brief. It noted simply that the checklist required judicial consideration, 'inter alia' of the child's age and wishes, the likely effect on the child of ceasing to be a member of the birth family, and the child's relationships with relatives. ${ }^{71}$

For some, this approach will be surprising because of its focus only on the child. There is no explicit mention in the checklist or in the Court's analysis at this point of the rights of the parents, separate from the child. It may be that the context of the case provides part of the answer to this question. The ECtHR was, of course, referring here to the issue of placing a child for adoption. It might be said that, by the time a case reaches this point, the rights of the parents have already been weighed and assessed, but have been required to give way to the child's interests because of the need to protect the child from harm. That reasoning is likely to be the basis for Simmonds' view is that $Y C$ is limited in scope to public law cases:

although the ECtHR has been happy to sideline parental rights when dealing with abuse and neglect of children and the need for alternative care, it is less likely to do so in questions relating to, for example, contact, residence and relocation. ${ }^{72}$

It is in these central private law areas that, for Simmonds, the core of the difference between the English domestic cases and the ECtHR exists, and here 'the academic objections to the compatibility of the different approaches remain in this context as cogent as ever' ${ }^{73}$

The question therefore is whether the ECtHR's analysis in $Y C$ will be applied, mutatis mutandis, to disputes between parents about the upbringing of the children (that is, private

\footnotetext{
${ }^{70}$ Ibid.

${ }^{71}$ YC v United Kingdom at [135].

${ }^{72}$ Simmonds (n 12) 501.

${ }^{73}$ Ibid.
} 
law disputes) as well. The complication in those cases is that there will be far less justification for focusing on the child's interests at the expense of the parents', and therefore the question of whether the English law's welfare approach, informed by its checklists, can be said, in general, to be a broad reflection of the article 8 requirements, or whether that is true only in the context of placing a child for adoption.

While there is no definitive evidence yet, one point that might support extending the same reasoning to private law cases comes from the fact that the source of many of the statements of principle in $Y C$ come from the child abduction (that is, private law) case of Neulinger $v$ Switzerland. It remains at least possible, looking at the analysis in $Y C$ and other cases, ${ }^{74}$ that the ECtHR may now see an English welfare analysis using the welfare checklist as asking questions and demanding analysis in much the same way as that demanded by the substantive limb of article 8 .

In order to understand the argument for why this approach might yet be said to give due weight to the rights of parents and other family members in a welfare analysis, we must turn back to the domestic cases. It may be that part of the reason why there now appears to be less of a 'conflict' between domestic and ECtHR approaches is that we have a clearer understanding of what the domestic approach actually means.

\section{WELFARE IN ENGLISH LAW}

As noted earlier in this chapter, ${ }^{75}$ many of the human rights criticisms that have been levelled against the English welfare approach take as their basis broader and well-established criticisms of the welfare principle. However, as I have suggested before, ${ }^{76}$ it might be thought that some of the criticisms appear to be based on something of a parody of what that principle involves. For example, Choudhry and Fenwick's leading article on this debate starts by summarising the welfare approach in this way:

its meaning is well understood amongst family lawyers: in decisions concerning children, the welfare of the child is to be the single deciding factor, that is, paramount

\footnotetext{
${ }^{74}$ See in particular $R$ and $H v$ United Kingdom (App No 35348/06) [2011] 2 FLR 1236 at [77], where the ECtHR explains that an assessment of the factors contained in the equivalent of the welfare checklist in Northern Ireland's adoption legislation (article 9 of the Adoption (Northern Ireland) Order 1987) would, so long as done properly, be compliant with article 8 .

${ }^{75}$ Above, text at $\mathrm{n} 23$.

${ }^{76}$ See R George, Ideas and Debates in Family Law (Hart Publishing 2012), ch 7.
} 
over, and in fact displacing, all other considerations. ${ }^{77}$

However, while such a summary is not unusual, I would respectfully suggest that it lacks crucial nuance and, indeed, sets up something of a straw man in the welfare versus rights debate. Two particular questions might be raised. The first is whether the welfare of the child can be said to be a 'single ... factor' and, perhaps following from that, whether it is right to say that welfare 'displac[es] all other considerations'.

When a judge, or anyone in fact, says that $x$ is in the child's welfare, that statement represents the conclusion of an analysis of many factors - indeed, of all factors which bear on the decision about the child's upbringing, either directly or indirectly. This analysis expressly includes the rights of parents, and expressly requires a careful balancing of the competing considerations. In the leading interpretation of the welfare principle, ${ }^{78}$ the House of Lords said this:

in applying [the welfare principle], the rights and wishes of parents, whether unimpeachable or otherwise, must be assessed and weighed in their bearing on the welfare of the child in conjunction with all other factors relevant to that issue. ${ }^{79}$ It might be said that the instruction to consider these rights 'in their bearing on the welfare of the child' is where the welfare principle falls down. However, it must be remembered that the welfare principle applies only to disputes that are specifically about an aspect of the child's upbringing, not to disputes where the child is merely part of the case. ${ }^{80}$ Any rights of a parent (or other party) that are in no way connected with the child's welfare ${ }^{81}$ are also, ex hypothesi, in no way connected with the substantive aspects of the case when that case is only about the child's upbringing. ${ }^{82}$ It therefore seems unsurprising that these factors should not be considered; conversely, any rights that are connected with the child will be relevant and will therefore be 'assessed and weighed'.

${ }^{77}$ Choudhry and Fenwick (n 18) 456 citing, after the words 'single deciding factor', $J v C$ [1970] AC 668 (HL).

${ }^{78}$ Despite pre-dating the Children Act 1989, this case interprets a near-identical provision from earlier legislation and remains the leading understanding of the welfare approach.

${ }^{79} J v C$ [1970] AC 668 (HL) at 715.

${ }^{80}$ Above, n 5. See also J Eekelaar, 'The Role of the Best Interests Principle in Decisions Affecting Children and Decisions About Children' (2015) 23 International Journal of Children's Rights 3.

${ }^{81}$ I suggest that the phrase 'connected with the child's welfare' is synonymous with having 'bearing on the welfare of the child'.

${ }^{82}$ Rights to do with procedure, in particular those associated with the right to a fair trial under article 6 and the procedural aspects of article 8 , might be different, though since these procedural rights exist because procedure is crucial to outcomes, their importance can be linked directly to the substance of the case. 
So, 'when all the relevant facts, relationships, claims and wishes of the parents, risks, choices and other circumstances are taken into account and weighed, ${ }^{83}$ the course of action to be followed is the one that most promotes the child's welfare. Does that mean that the courts assess welfare 'without regard for' the rights, interests or welfare of others? ${ }^{84}$ Surely not. The fact that A's (qualified) rights do not prevail in the analysis does not mean that there was no 'regard' given to them. One might note that the child's (qualified) rights have not necessarily prevailed either. Consider, for example, a court order authorising a child to be taken into local authority care. ${ }^{85}$ The article 8 rights of each parent are, of course, involved in such a decision; but so too are some of the child's article 8 rights. Welfare is a composite idea, whereas rights can be atomised. ${ }^{86}$ I have a right to $x$, to $y$ and to $z$, all of which are separate and freestanding, and which may indeed conflict with one another at times. ${ }^{87} \mathrm{My}$ welfare interest, on the other hand, is always made up of many considerations: those considerations may well be conflicting, but the welfare conclusion sits above such conflict, and reflects the end result of the analysis rather than a discussion about which factors should be included.

For these reasons, I would respectfully suggest that to say that welfare 'displaces' all other considerations risks conflating 'a welfare decision' with 'the factors which are used to make a welfare decision'. The conclusion of any gestalt, complex, multi-factorial analysis like a welfare analysis will overtake (or displace) the individual considerations which feed into it, but that does not mean that those considerations are unimportant, nor that they are not given their due weight and respect. It is the result of a balance - and if seen in this way, it may seem less surprising that the ECtHR would not see any inherent incompatibility between the English welfare approach and the substantive requirements of article 8.

In passing, it might be noted that this argument does not necessarily imply that the welfare checklist, by itself, reflects the requirements of an article 8 analysis. The checklists are focused on issues from the child's perspective, but of course they are not exhaustive lists

${ }^{83} J v C$ [1970] AC 668 (HL), 710 (emphasis added).

${ }^{84}$ Herring, 'The Human Rights Act and the Welfare Principle in Family Law: Conflicting or Complementary?' (n 19) 225.

${ }^{85}$ Children Act 1989, s 31.

${ }^{86}$ That does not mean that either the idea of rights or a rights analysis in any given case is straightforward. Far from it. See generally Eekelaar (n 22), ch 6.

${ }^{87}$ The child's rights in a care case, for example, may be in conflict with one another: as a basic example, the right to protection from inhuman and degrading treatment may be in conflict with the right to respect for family life; and different aspects of the right to respect for private and family life may be in conflict with each other: see Neulinger $v$ Switzerland at [136]. 
of considerations. They are expressly stated to be considerations for the court to take into account 'in particular', and so other factors can and should be included. It would go too far to say that the welfare checklist broadly reflects the requirements of article 8 ; but it may yet be arguable that the welfare principle, understood as suggested here, does reflect those requirements.

\section{CONCLUSIONS}

Given the central role of the welfare of the child as a legal concept across Europe, the question of whether this approach is compliant with the requirements of human rights instruments is of the highest importance. If there were an inherent incompatibility between this core legal approach and the right to respect for private and family life, there would be an urgent need to re-think domestic child laws across the Council of Europe member states.

However, the suggestion from this chapter is that such a reassessment is not in fact required. While there are still clearly issues to clarify - such as whether explicit discussion of individual factors within the decision-making process is required or whether, conversely, an overall assessment is adequate - the ECtHR's approach now seems to suggest that a best interests analysis that prioritises a child's welfare within a full assessment of the overall family situation will be compliant with article 8 . The bigger challenge for states across Europe, to judge by those cases that succeed in the ECtHR, may be in ensuring that the procedural requirements of article 8 are complied with, and that the court is in a position in fact to undertake this wide-ranging assessment of the individual family's situation.

\section{RECOMMENDATIONS FOR FURTHER READING}

S Choudhry and H Fenwick, 'Taking the Rights of Parents and Children Seriously: Confronting the Welfare Principle under the Human Rights Act' [2005] Oxford Journal of Legal Studies 453.

S Choudhry and J Herring, European Human Rights and Family Law (Hart Publishing 2010). J Eekelaar, Family Law and Personal Life (Oxford University Press 2007), ch 6.

J Eekelaar, 'The Interests of the Child and the Child's Wishes: The Role of Dynamic SelfDeterminism' [1994] International Journal of Law and the Family 42.

J Eekelaar, 'The Role of the Best Interests Principle in Decisions Affecting Children and Decisions About Children' (2015) 23 International Journal of Children's Rights 3

R George, Ideas and Debates in Family Law (Hart Publishing 2012), ch 7. 
S Harris-Short, 'Family Law and the Human Rights Act 1998: Judicial Restraint or Revolution?' [2005] Child and Family Law Quarterly 329.

J Herring, 'The Human Rights Act and the Welfare Principle in Family Law: Conflicting or Complementary?' [1999] Child and Family Law Quarterly 223.

R Mnookin, 'Child-Custody Adjudication: Judicial Functions in the Face of Indeterminacy' (1975) 39 Law and Contemporary Problems 226.

H Reece, 'The Paramountcy Principle: Consensus or Construct?' (1996) 49 Current Legal Problems 267.

J Wallbank, S Choudhry and J Herring (eds), Rights, Gender and Family Law (Routledge 2010). 